\title{
IMPORTANCE OF STRATEGY IN MODERN MILITARY ACTION
}

\author{
Mihai-Marcel NEAG \\ "Nicolae Bălcescu" Land Forces Academy, Sibiu, Romania \\ mmneag@yahoo.com
}

\begin{abstract}
The issue of studying the physiognomy of military actions in the light of the influence of the main military strategy schools is integrated into the field of military art as an objective necessity of a relevant analysis of risks and threats that may affect military force and, consequently, to identify effective means and methods of response against them. The conclusion that emerges from the study is that military action will remain the beneficiary of forward-looking thinking and initiative, in which past moments are primarily considered as a source of lessons learned to increase the effectiveness of the actions to come.
\end{abstract}

KEYWORDS: strategic thinking, war, military strategy, military action

\section{Introduction}

Few social phenomena have accompanied and marked the evolution of human society as war has done. The current security environment consists of all political, economic, social, informational and military systems, factors and processes that interact, in the current globalizing context, creating a space characterized by certain constants and several variables. No human society, as far as we know, has developed and does not develop linearly. The life of a society knows symmetrical, disymmetric and asymmetrical moments, rapid developments and stagnations, progress and regressions, normal situations, but also abnormalities, crises and conflicts.

War, as a social phenomenon, with objective causes, conditions and laws of unfolding, has always occupied an important role and weight in the evolution of human society. Viewed from this perspective, it has been, is and will be studied by specialists for the purpose of knowing and enacting the laws that govern it, in order to mitigate human and material losses, to mitigate its effects on human society and, last but not least, to determine and investigate the most important factors that compete to achieve its political-military purpose.

The problem of the study of force groups and the physiognomy of military actions as influence of the main schools of strategy is integrated into the scope of the necessary steps required in military art as a result of the objective need that, following a relevant analysis of these new risks and threats to humanity, means, methods and effective means of prevention and retaliation against them be identified. This raised the issue of making the use of forces and means more efficient by exploiting factors and characteristics of military structures that contribute to increasing their fighting potential.

In this regard, with the development of the means of combat under the impact of the technical-scientific revolution in the military field, starting from the characteristics 
of the stategia schools, one of the great challenges for specialists in the field was the achievement at the highest possible levels of mobility, protection and firepower, basic components of the combat power of subunits, units and large units in military actions (Raclaru, 1993).

\section{Elements of Strategic Thinking of Military Operations and Forces}

Under the current conditions, the conduct of conflicts is constantly changing, adapting to the new requirements. This is interesting to watch in this adaptation to the new requirements influence the strategy schools. Regarded as a quality of military systems, this adaptation is one of thefactors that decisively influence success and reduce the cost of a military confrontation.

The essential expression of functional superiority, adaptation manifests itself on multiple planes "... being in direct relation to the suppleness of management and execution, with the achievement of an increased density of actions, fire, forces and means, dams and obstacles, with the ability to diminish the limiting effects of external factors" (Arsenie, 1987, p. 71).

War and armed struggle were the central topics of analysis for policy makers, regardless of the evolutionary stage of humanity, the content of military doctrines or the level of endowment of armies. Because of its particular complexity, the political-military theorists did not intend to analyze the war as a whole, with all its implications and repercussions, realizing that an approach of this magnitude would undoubtedly have been doomed to failure. Edifying, in this sense, are the very titles of the writings of some of these renowned analysts: Sun Tzî - "The Art of War", Erasmus from Rotterdam - "About War and Peace", Niccolo Machiavelli - "The Art of War", Karl von Clausewitz - "About War". Analyzing these theoretical works we can see that their subject of study was the strategy of war.
It is apparent from their content that this strategy directs the state's cumulative effort to preserve or achieve fundamental objectives of its policy - integrity, independence and sovereignty. Thus, it is clear that the specialists' warning of the particular responsibility that the political factor assumes when adopting the decision to involve the state in an armed confrontation is clearly outlined. The historical evolution of the peoples was based on the art of political-military leadership.

The military strategy, at the beginning of its development, was considered in the field of military knowledge a science of military sciences and by the end of the $19^{\text {th }}$ century it was defined as "... synthesis, integration of the entire military art, its generalization, its philosophy" (Onişor, 1999, p. 25).

The American school considers strategy (F.M. 3.0, 2017, p. 9) as the art and science of deploying and hiring military forces and other components of national power in a synchronised system of security of national or multinational objectives. "The main challenge for US security and prosperity is to reaffirm long-term strategic competition with countries that in the National Security Strategy are described as revisionist powers" (Orchard, 2018). The American national military strategy, derived from national security policy, is the basis of all operations associated with war, as well as those other than war. Military operations influence and are influenced by political trends and the use of other instruments of power. The military goal in the war is to achieve a quick and decisive victory. Military power is required, and it provides for its development and modernization to impose the rules and interests of the American people. The last few years have brought to the fore cyber defense and protection of critical infrastructure, essential components of the protection of the American economy. 
The German school according to Karl von Clausewitz's work, the strategy is to use combat for the purpose of war. In fact, the strategy is only in combat, but her theory must deal with the agent of this specific activity, the armed forces because they give the fight. The strategy must study the struggle about its possible results. The military strategy can be considered as the art of using all distinct state means for the concrete realization of political options through the use or threat of the use of military force. According to this school, the causes in the strategy that determine the use of combat can be divided logically into moral, physical, mathematical, geographical and statistical elements.

First class would belong to all that is provoked by qualities and moral effects; of the second class the size of the armed forces, their composition; of the third class the angle of the operating lines, the concentric and eccentric movements; fourth class influence of the territory through dominant points, mountains, rivers, forests, roads; of the fifth class means of supply. The federal military must be prepared to help "maintain national security", to devote themselves equally to the two missions, internal and external. The military's strategic guidelines are described in the "White Paper on Security Policy", according to it, national defence within NATO and the EU is the primordial mission of the Bundeswehr and includes specifically scenarios such as cyber attacks or hybrid conflicts.

The Chinese school has the foundations in the work The Art of War, also known as Ten Articles, by Sun Tmy, which is recommended not only as a synthesis of Chinese military thinking from two millennia ago, but also as one of the monuments of military literature of all time.

To achieve its status as a global power, China is modernising its defence and security system after high economic growth and improved technological capabilities. Beijing's most important objectives are regional importance and increased international influence, and for this it needs economic growth, diplomacy and military power. Chinese strategic documents see the existence of an army capable of starting wars and fighting, discouraging possible enemies and protecting China's nterests as the main requirement for such development. China also conducts influence missions against cultural institutions, media organisations, business and academia, American political communities, and other countries, against international institutions, in order to achieve results that could support its strategic and military objectives (Ioniță, 2019). The human factor (the morale of the people and the army, the quality of the command), the physical conditions (land and weather), the doctrinal element are recommended to be taken into account when calculating the ratio of forces of chances. "Victory can be created" - says Sun Tzî. But that's not enough number or force. That is why he constantly insists on the investigation of intelligence, price, ability, analytical and synthesis capacity, on the creative initiative. Morale, the quality of the command and the skills of the troops, the organization, discipline, their order, the provision of weapons and supplies, using the advantages of time and terrain, using a strategy and tactics appropriate to their own situation and those of the enemy - are the factors of victory. In such an international environment, defined by competition rather than cooperation, the net assessment reveals the opportunities of key decision-makers when information has rendered nuclear weapons useless and the conventional conflict has become too problematic to achieve political objectives.

Chinese intelligence services act practically like all other state structures, regardless of the names of strategic concepts and the strategies they follow. Whether it is the use of human relations as a bridge over cultural and linguistic barriers in the most difficult environments or to support the 
development of cultural skills or crosscultural skills, the growth of security culture or the net assessment of the adversary, the conclusion is that supported centuries ago by Sun Tzî: "Final excellence is not to win every battle, but to defeat the enemy without ever fighting".

Soviet military art is divided - in terms of the scale of its military actions into strategy, operative and tactical art. Strategy holds the main place in military art. Between strategy, on the one hand, and operative and tactical art, on the other hand, there is a close connection. The military strategy has a leading role towards them, as it defines the general purpose of the actions, forces, means and procedures for solving the tasks that stand addressing the risks and threats facing the UK; identifying the reforms needed for government systems and structures to achieve the objectives.

The main priority is the internal defence of the United Kingdom, a second priority is to protect the interests of the United Kingdom and commonwealth states abroad, and the third priority is to respect the uk's obligations under the NATO Treaty and the international coalition in support of the UN (Negoiţă, 2020).

French school, F. Foch remained until the end of his life dominated by the theocratic idealistic conception, which was, to a large extent, the basis of his military thinking. Foch primarily considers the will of the commander he instills and subordinates, the genius, talent, inspiration, will and energy of the commander gives strength to an army. General André Beaufre is a modern author, addressing complex aspects of political-military reality: nuclear deterrence, indirect strategy, revolutionary warfare, total strategy form its themes of predilection. According to him, the strategy should not be a single doctrine, but a method of thinking, allowing the classification and ranking of documents and then the choice of the most effective procedures. He believed that the science of strategy lies in the abstract game that resulted, as Foch said, from the opposition of two wills. It is art that allows, regardless of any technique, to dominate the problems that put sit itself any struggle, precisely to allow the use of techniques with maximum effectiveness. It is therefore the art of the dialectic of the forces or, more precisely, the art of the dialectic of the wills that uses force to resolve their conflict. The aim of the strategy is to obtain the decision by creating and exploiting a situation that leads to a moral disintegration of the opponent sufficient to make him accept the conditions imposed on him.

Convinced of its capabilities as a world power, France's defence policy wants to assume military responsibilities throughout the world and where it considers its geopolitical interests to be jeopardised, directly or indirectly. In the current strategic context, French political analysts appreciate that, for the first time in its history, France no longer knows a direct military threat, manifested near its borders, but new ones have emerged that may directly affect its security.

At the heart of France's national security and defence policy is the "sovereign capacity" of defence within the national territory. It follows the European dimension of security within a weakened international system and in the presence of emerging actors who openly try to undermine it. However, the European dimension of France's security is not synonymous with its participation in the common security and defence of the European Union, although apparently there should be a great degree of consistency between the two. The third level of French national security and defence policy is the ally. French defence and security strategic documents consider NATO to be a key component of European defence. The fourth level of France's national security is strategic partnerships outside the Euro-Atlantic area, especially with the states in those regions of strategic interest for Paris. It would be 
primarily Australia and India, but also Japan, Singapore, Indonesia and Vietnam. Nuclear deterrence remains essential to France's defence strategy, as it protects it from any state aggression against its vital interests, from wherever and in whatever form it may come. The French strategy emphasises the ability of the armed forces to stop the war, to limit the conflict and not to support them, since, although conventional, they can be long-lasting, with uncertain and, above all, particularly costly results.

\section{Possible Developments in Military Actions in the Current Context}

The directions and orientations of the evolution of the military phenomenon determine how military actions evolve, intuiting two components: firstly, the diversification and modernization of classical military actions and, secondly, the emergence and development of new types of military actions, both sides being found in the evolution of military science and art, in appropriate doctrines and concepts because the hostilities in the battlefield of the future represent "not only a confrontation of forces and means (material), but also a confrontation of intelligence (spiritual), which confers military action in addition to dynamism and violence, tension, will and firmness" (Military Science Treaty, 2001, pp. 181).

This likely development has significant implications for the structure of the armed forces as a whole and each component, on the equipping of forces with equipment, combat techniques and materials, and on the preparation of commands, major states and troops.

The implementation of modern technologies, together with the new requirements imposed by the evolution of the security environment on the way of preparation and conduct of actions can materialize in the requirement that military structures acquire greater operational autonomy, so that they can execute rapid, decisive, dynamic and manering actions, continuous and coordinated in the smallest detail.

Spectacular developments in science and technology have a special effect on the military field, requiring reorientations, rethinks and reorganizations in the system of modern military action. Also, the new missions and the diversification of the classical ones, determine the need to achieve multi-role units and formations, with a modular and flexible structure, in order to be able to fulfill the widest range of missions and design the force according to the specifics and size of the crisis or conflict, achieving both increased efficiency and speed in achieving the objectives.

The structure of the units, sub-units and formations must ensure their polyvalence in carrying out missions on a wide spectrum of confrontation, from peacekeeping, humanitarian or searchseeking, peace-enforcement actions to the contribution to anti-terrorist, informational or psychological actions, which require special specialization.

At the same time, their structure must be modular and flexible, with the possibility of adapting their components according to the nature of the mission and the conditions under which the actions are carried out, and the combination of the different components of the smaller stages in the subordination of the higher ones should be done quickly, without changing the means, documents and procedures of management and action.

A special role in the realization of this goal is played by combat technique, management and logistics systems and these, in turn, must be inteoperable, flexible and modular, possible to integrate into different systems as a destination, composition and missions, without essential changes at the level of the basic organisational entity. As far as weapon systems are concerned, they have evolved 
in two directions, the effects of which are convergent.

The first direction is built by the improvement of the tactical and technical characteristics of the classical weapons (tanks, cannons, missiles, airplanes, helicopters, battleships, etc.), the modernization of the equipment used and the realization of complex and efficient combat platforms, with high precision of hitting and at increasing distances, in any environment and conditions.

At the same time, new equipment and technologies have emerged, digitized, in fact, weapons systems that link in a single complex both the means of surveillance, identification and localization (determination of coordinates, characteristics, fingerprint and membership), as well as the means of data processing and hitting, neutralizing or affecting the forces and means of the opponent.

Force management systems are subject to the same modern operational requirements, in order to be able to form and lead forces designed to resolve a crisis or armed conflict situation, both in terms of the structure of the governing bodies and in terms of equipping equipment and materials.

The dynamic, manevrier and flexible nature of military actions requires reconsideration of the structure of headquarters and major states, so that they can cover the full range of missions and areas of responsibility, starting with the management of information about troops own, adversary, terrain and weather, management of available resources and materials, as well as for solving problems of multilateral provision of logistical support.
The concern for the diversification of the processes of action is one of the essential prerequisites for achieving surprise in modern warfare. Adopting new and diversified action processes, devoid of schematics and outside the templates creates the conditions for the conquest, maintenance and exploitation of the initiative in order to achieve surprise.

\section{Conclusions}

There is no doubt that the future will highlight other trends and perspectives regarding the evolution, content and typology of armed conflicts, as a natural response to the multitude of military and non-military risks to the national security of states and global and regional security and stability. The implementation of the new ways of conducting the third millennium war is in fact the constant concern of military specialists in preventing and resolving armed conflicts and removing risks and threats by achieving maximum results with the lowest possible material efforts and human losses, but involving a maximum intelligence effort.

I believe that the trends in the evolution of the content of military art are closely correlated with the evolution of the military phenomenon as a whole. Under the influence of the factors underlying the changes in the physiognomy of modern warfare, military art continuously adapts its principles, methods, processes and rules for preparing and carrying out military actions so that they correspond to the organizational, structural and endowment transformations specific to the modern military system. 


\section{REFERENCES}

Academy of Scientists, Department of Military Science. (2001). Military Science Treaty. Vol. I, Bucharest: Military Publishing House.

Arsenie, V. (1987). Principles of Armed Struggle - Military Art Study. Bucharest: Military Publishing House.

Capital. (2021). Available at: https://www.capital.ro/noua-strategie-militara-a-rusieimai-putina-cantitate-mai-multa-tehnologie.htm, accessed on 22 February 2021.

Headquarters, Department of the Army USA. (2017). F.M. 3.0, Operations. W / Basic Incl C1).

Ioniţă, L. (2019). A Chinese concept for the $21^{\text {st }}$ century: Three wars, no fight, available at: https://en.monitorulapararii.ro/a-chinese-concept-for-the-21st-century-three-wars-no-fight1-18728, accessed on 24 February 2021.

Negoiţă, S. (2021). Revizuirea strategică a apărării şi securităţii revine pe agenda de priorităţi a Guvernului britanic, available at: https://monitorulapararii.ro/revizuirea-strategica -a-apararii-si-securitatii-revine-pe-agenda-de-prioritati-a-guvernului-britanic-1-32618, accessed on 24 February 2021.

Onişor, C. (1999). Military Strategy Theory. Bucharest: A.I.S.M. Publishing House.

Orchard, Ph. (2018). O nouă strategie de apărare a SUA pentru viitor, available at: https://www.agerpres.ro/geopolitical-futures/2018/02/09/o-noua-strategie-de-aparare-a-suapentru-viitor--52128, accessed on 22 February 2021.

Răclaru, O. (1993). Trends on increasing the mobility of land troops in foreign armies. Newsletter on Knowledge of Foreign Armies, No. 2, 36. 